\title{
SOME PHYSIOCHEMIGAL AND RHEOLOGICAL PROPERTIES OF PREPARED SPREADABLE TOFU BLENDS
}

\author{
By \\ Shafika A. Zaki \\ Department of Food Science, Faculty of \\ Agriculture, Cairo University, Giza, \\ Egypt.

\section{Hala M. Nagi} \\ Department of Food Science, Faculty of \\ Agriculture, Cairo University, Giza, \\ Egypt.

\section{Abeer F. Zayan} \\ Dairy Research \& Technology \\ Department, Food Tech. Res. Inst., \\ Agric. Res. Center, Egypt

\section{Amira S. Abd-Elsalam} \\ Dairy Research \& Technology \\ Department, Food Tech. Res. Inst., \\ Agric. Res. Center, Egypt
}

\section{Research gournal Specific Fducation}

Faculty of Specific Education

Mansoura University

ISSUE NO. 49, JANUARY. 2018

$$
\text { مجلة بحوث التزبية النوعية - جامعة المنصورة }
$$




\title{
SOME PHYSIOCHEMICAL AND RHEOLOGICAL PROPERTIES OF PREPARED SPREADABLE TOFU BLEND
}

\author{
Shafika A. Zaki * \\ Hala M. Nagi * \\ Abeer F. Zayan ${ }^{* * *}$ \\ Amira S. Abd-Elsalam**
}

Abstract

Recently, the use of soy and soybean products has been grown in food industry. The study objective of the research is to prepare products of spreadable tofu with different flavors. Six formulated spreadable tofu with different flavors were prepared; control without addition, and with chopped green olives, ground black pepper and chopped green peppers; sugar; guava pulp, and peach pulp. The spreadable Tofu blends were subjected to chemical and sensory evaluation to ensure different qualities. L values were decreased with adding fruit, vegetable and spices to tofu. It took 80.16, 79.37, 76.12, 79.28, 75.70 and 75.40 for control, T1, T2, T3, T4 and T5 in respective order. The same trend was observed of $\mathrm{A}$ value and $\mathrm{B}$ values were increased, while yellowish was decrease because of tofu. Obtained data showed that meltability value in control, T1, T2, T3, T4 and T5 ranged (49-72), (33-55), (42-53), (35-71), (32-70) and (31-70), respectively. The control showed the highest value compared to other treatments. Texture properties of spreadable tofu blend indicated that the ranges of hardness presented $(1.2-8.4 \mathrm{~N})$, cohesiveness $(0.19-0.63)$, springiness $(2.48-8.00 \mathrm{~mm})$, gumminess $(0.6-2.6 \mathrm{~N})$ and chewiness $(3.69-12.66 \mathrm{~m} . \mathrm{j})$. The highest hardness values was treatment $\mathrm{T} 4$ which contain tofu with $20 \%$ guava pulp compared to control and other treatments.

Key words: spreadable tofu, texture properties, guava pulp, peach pulp, green peppers, black peppers, green olives.

* Department of Food Science, Faculty of Agriculture, Cairo University, Giza, Egypt.

Dairy Research \& Technology Department, Food Tech. Res. Inst., Agric. Res. Center, Egypt. 


\section{Introduction:}

Soybeans have been primarily consumed by humans after being fermented and turned into a curd. Tofu, a bland, cheese-like substance made from the whey of fermented soybeans, is the most common example of this kind of soy-product. Bolla (2015) assured that soybeans are high in quality protein soybeans contain all the essential amino acids, in adequate amounts needed for health and two- three servings of soy provide $\sim 15-20 \mathrm{~g}$ protein.

Tofu appeared to be the most popular among all soy products and also called soy bean curd. It has been made by coagulating hot soymilk with some food grade chemicals such as calcium chloride, magnesium chloride, calcium sulfate, acetic acid and citric acid (Mchugh, 2016).

The two most commonly used salt coagulants were calcium sulfate (gypsum) and magnesium chloride combined with calcium chloride (nigari salts) as reported by Rekha and Vijayalakshmi (2013) and Kang et al. (2014).

Vegetables and fruits seemed to be high in fiber and contain many vitamins and minerals as well as hundreds of beneficial plant chemicals (phytochemicals). Diets rich in vegetables and fruit could benefit the heart by lowering blood pressure, cholesterol levels, and inflammation and improving insulin resistance and blood vessel function and weight gain, a lower risk of stroke (Slavin and Lioyd, 2012 and Willett, et al., 2013).

Guava, a popular fruit of tropical and subtropical countries, contained $80 \%$ moisture $20 \%$ dry matter, $1 \%$ ash, $0.7 \%$ fat and $1.5 \%$ protein (Chauhan, et al., 2014). The utility of guava as functional foods have been increasing with the main traditional use preferred as an anti-diarrheas agent for treatment of gastroenteritis, dysentery, stomach, antibacterial colic pathogenic germs of the intestine, other medicinal properties of guava includes treatment of diabetes, hypertension, inflammation etc. (Metwally, et al., 2010).

Chauhan, et al. (2014) and Lim, et al. (2011) noted the preference of fresh fruit for consumption but seasonal availability limits consumption 
of fruit throughout the year. Hence processed products such as puree, paste, canned slices in syrup or nectar are developed and marketed.

Peaches, considered among the first 3-5 fruit species regarding flavor and complex chemical composition, comprised of 10.0-21.5\% dry matter, $5-12 \%$ total sugar, $0.4-1.3 \%$ protein, $0.2-0.7 \%$ pectin, $0.6-0,86 \%$ minerals and vitamins (Iordănescu and Micu, 2012).

Peppers, important vegetables, have been used fresh or as a spice (Marinova, et al. 2005 and Igbokwe et al., 2013).

Black pepper, one of the most popular spice products in oriental countries, has largely used as a flavoring agent in foods (Mueller and Hingst, 2013). The components of the pepper's extract that contribute to its value as a food additive included the volatile oil for its aroma and the alkaloid compounds for the pungency (Brewer, 2011).

Olives as good source of several vitamins and minerals, some of which were added during processing, such as vitamin E, cholin, niacin, vit. A, B6, thiamin calcium, iron, and copper (Rines and Ardehali, 2013, Abbaspour et al., 2014, Emkey and Emkey, 2012 and Hui, et al. (2015).

In the last few decades, palm oil's application in food industries has exponentially grown for the texture, the fragrance and the neutral taste it guarantees in the finished products. Its two major fractions consisted ofthe low-melting liquid fraction (known as palm olein, 65\%-75\%) and the highmelting solid fraction (known as palm stearin, 30\%-35\%) as reported by Henson (2012).

The present investigation aimed to study the effect of mixing tofu with some vegetables and fruits on some physiochemical and rheological properties of spreadable tofu products with different flavors.

\section{Materials and Methods}

\section{Materials}

a. Soybean seeds (Glycine Max., L., commercial variety) were obtained from Legumes Research Dep., Field Crops Research Institute, Agriculture Research Center, Giza, Egypt. 
b. Palm oil from Efico star Co. Egypt

c. Skimmed milk powder from Fonter ALTD; Auckland, New Zealandd. Whey powder from Agropur Granby, Canada.

d. Emulsifying salt (Joha S9 special) from Arabian Food Industries Co. Egypt

e. green olives, ground black pepper ,chopped green peppers, sugar; guava , peach salt (Nacl), from local market.

f. Stabilizers (corn starch, CMC, soluble starch, modified potato starch, Guar gum) from AVEBE U.A. The Netherlands.

g. Q3 \{Sodiumcarboxymethyl Cellulose (E 466) - Gur gum (E 412)\} stabilizer from BK Giuliani GmbH, Ladenburg, Germany.

\section{Methods}

\section{Preparation of Tofu:}

- Cooking soymilk in a steam jacketed kettle at $90-95^{\circ} \mathrm{C}$ for $15-20 \mathrm{~min}$. (Groen, Adover Industries Co., Elk village, USA.

- Weighing $100 \mathrm{~kg}$ soymilk in bucket and reheat it at $85^{\circ} \mathrm{C}$.

- Adding a warm coagulant powder $(0.5 \%$ calcium chloride) to soymilk at $70-80{ }^{\circ} \mathrm{C}$ with agitation using a paddle.

- After forming curd allowing it to stand for $15-20 \mathrm{~min}$.

- Breaking up the curd evenly and transferring it using a ladle into a forming box lined with moistened cloth, and then covering the box with lid.P

- Pressing with a suitable pressure (at 50 psi for 15-20 min.

- Placing the forming box with tofu in a cooling tank, resetting to the tofu for $5 \mathrm{~min}$, unfolding the cloth and removing the tofu.

- Cutting the tofu into pieces (about $3 \times 4 \times 5 \mathrm{~cm}$.

- Packing \& Immersing tofu in plastic bags without any addition in chilled water (Benassi et al., 2011) and (Agrahar, 2014). 


\section{Preparation of Spreadable tofu with some commodities}

The suitable amounts of raw materials (soy curd (Tofu), Skimmed milk powder, whey proteins, palm oil, Stabilizers $\left\{\left(\mathrm{Q}_{3}\right)\right.$ Sodium carboxymethyl Cellulose + Guar gum $\}$, emulsifying salts and water were used for preparing spreadable tofu blends. The raw materials with added commodities and water were added consecutively in laboratory processing Kettle (Thermomix TM 31 made in Australia Pty Ltd 2010) as mentioned by Awad (2014). All blends were adjusted to contain 58\% moisture, 50\% fat/DM and 2.5\% emulsifying salts (Joha S9 special). Some vegetable, fruits and spice were added to the formula as a substitute of tofu. The mixture was cooked for $10 \mathrm{~min}$ at $85-90^{\circ} \mathrm{C}$ using indirect steam at pressure $2-2.5 \mathrm{~kg} / \mathrm{cm} 2$. The mixture was hot filled into wide mouth glass jars and capped directly after filling. The resultant spreadable tofu was analyzed when manufactured and after 1,2 and 3 months of storage in refrigerator $\left(5 \pm 2^{\circ} \mathrm{C}\right)$. The mixture was cooked for $10 \mathrm{~min}$ at $85-90^{\circ} \mathrm{C}$ using indirect steam at pressure 2-2.5 $\mathrm{kg} / \mathrm{cm} 2$ then was hot filled into wide mouth glass jars and capped directly after filling. The spreadable tofu samples were analyzed at $0,1,2$ and 3 months of storage in refrigerator $\left(5 \pm 2^{\circ} \mathrm{C}\right)$.

Formulations of all the six tofu blends consisted of skim milk powder $(50 \mathrm{~g})$, whey powder $(30 \mathrm{~g})$, and emulsifying salts $(25 \mathrm{~g})$. The other remaining commodities per $1000 \mathrm{~g}$ were different in the six prepared blends as follows:

Control (C): 454.75soy curd, 172.03Palm oil, 30Q 3 , $238.22 \mathrm{~g}$ water.

T1: 404.75soy curd, 170 Palm oil, $35 \mathrm{Q}_{3}, 50$ chopped green olives and $235.25 \mathrm{~g}$ water.

T2: 427.75 soy curd, $176.45 \mathrm{Palm}$ oil, $38 \mathrm{Q}_{3}, 0.2 \%$ ground black pepper and $2.5 \%$ chopped green peppers and 235.25 water $\mathrm{g}$.

T3: 434.75soy curd, $174 \mathrm{Palm}$ oil, $30 \mathrm{Q}_{3}, 20$ sugar and $236.35 \mathrm{~g}$ water.

T4: 404.75soy curd, 170Palm oil, 35Q $\mathrm{Q}_{3}, 200$ Guava pulp and $77.69 \mathrm{~g}$ water.

T5: 404.75soy curd, 170 Palm oil, 35 Q3, 150 Peach pulp and $63.52 \mathrm{~g}$ water. 
- Some physiochemical and rheological properties of prepared spreadable tofu blends

\section{Physicochemical properties:}

\section{- Determination of meltability property}

The meltability of blends was represented by the difference (Dt) between sample area at cooking time $\mathrm{t}(\mathrm{min})$ and that before cooking: $\mathrm{Dt}=$ At - A0; where At is the sample area $\left(\mathrm{mm}^{2}\right)$ in $\mathrm{t}$ min cooking and A0 is the initial sample area $\left(\mathrm{mm}^{2}\right)$. Meltability of spreadable tofu blend was tested as described by Wang and Sun (2002).

\section{- Color measurement}

Surface color of spreadable tofu with some additives samples were determined according to the tristimulus color system described by Francis (2000) using spectrophotometer (MOM, 100D, and Hungary). Color coordinates $\mathrm{X}, \mathrm{Y} \& \mathrm{Z}$ were converted to corresponding hunter $\mathrm{L}^{*}, \mathrm{a}^{*} \& \mathrm{~b}^{*}$, from where

Hue $(\mathrm{h} \epsilon=\operatorname{arc} \tan \mathrm{b} / \mathrm{a})$, chroma $\left[\mathrm{C}^{*}=(\mathrm{a} 2+\mathrm{b} 2) 1 / 2\right]$, intensity $=(\mathrm{a} 2$ $+\mathrm{b} 2+\mathrm{L} 2) 1 / 2$

Color coordinates according to formula given by manufacturer.

- L: value represents darkness from black (0) to white (10))

- A: value represents color ranging from red (+) to green (-)

- B: value represents yellow (+) to blue (-)

- C: Chroma

- Hue (he): tone angle or color

- Intensity: chromaticity of color saturation

The determinations were performed in triplicate, with the calibrated equipment, using 3 samples from each formulation indicated by Pathare, et al. (2012).

\section{Rheological properties}

- Texture profile analysis (TPA)

Texture profile analysis test of samples was done using a Universal Testing Machine (TMS-Pro) Food Technology Corporation, Sterling, Verginia, USA) equipped with $1000 \mathrm{~N}$ (250 lbf) load cell and connected to a 
computer programmed with Texture Pro ${ }^{\mathrm{TM}}$ texture analysis software (program, DEV TPA With holding time between cycle two second). A flat rod probe (49.95 $\mathrm{mm}$ in diameter) was used to uniaxially compress the samples with the following parameters conduction to $30 \%$ of their original height. The texture profile analysis test set condition was adjusted to a test speed $50 \mathrm{~mm} / \mathrm{sec}$; trigger force $1 \mathrm{~N}$, deformation $40 \%$ and holding $2 \mathrm{sec}$ between cycles). Each sample was subjected to two subsequent cycles (bites) of compression-decompression. Calculation described by Szczesniak et al (1963) and Bourne (1978) was used to obtain the following texture profile parameters (Hardness, Cohesiveness, Springiness, Gumminess and Chewiness)

\section{RESULTS AND DISCUSSION}

\section{- The preliminary Experiment}

\section{Soybean product}

In order to select, a product from soybean products as a base material for the present study, the experiment was conducted:

\section{Suitable emulsifying salts and stabilizers}

Different types of emulsifiers and emulsifiers were tested:

$\mathrm{Q}_{3}(3 \%)$ and special $\mathrm{S}_{9}(2.5 \%)$ were selected as emulsifying salts as the product had a good texture similar to cheese made from the natural milk.

\section{Appropriate flavors}

a. Artificial flavorings materials: Three materials were tested for flavor, i.e. Cheddar cheese, black peppers and green olives. Good results have given a high degree of sophistication in sensory judgment.

b. Natural nectars: Natural nectars of fruits, vegetables and spices were used.

Fruits (orange pulp - peach - guava - mango - strawberry -black berries - pomegranate- red plum) with different proportions.

Vegetables (chopped green peppers, chopped pickled green olives, chopped black olives, dried tomatoes and ground dried carrots with different proportions. 
Spices: different ratios of Black pepper with green peppers.

Based on the sensory judging, $15 \%$ peach pulp and $20 \%$ guava pulp were selected.

$5 \%$ chopped green olives and a mixture of $0.2 \%$ ground black pepper with $2.5 \%$ chopped green peppers was selected.

\section{Fat kind}

Different materials were tested: cocoa substitute butter - coconut oil - olive oil - Palm oil and shortening). Palm oil gave an excellent product that did not affect the flavor of the final product.

\section{- Instrumental analysis of color.}

From data in table (1), it could be seen that $\mathrm{L}$ value (which the whiteness of sample) was decreased with adding fruit, vegetable and spices to tofu. It took 80.16, 79.37, 76.12, 79.28, 75.70 and 75.40 for control, T1, $\mathrm{T} 2, \mathrm{~T} 3, \mathrm{~T} 4$ and $\mathrm{T} 5$ in respective order. The same trend was observed of A value (which reflect the blue and red color) and $B$ value (which reflect the yellowish color).

It could be concluded that whiteness of sample was increased while yellowish was decrease because of tofu, this results agree with Agrahar ( 2014) who found that $L$ values from 78.8 to 87 and $B$ values from 13.4 to 18.8 , and would easily gain acceptance in populations who consumed these products.

Table (1): Color characteristics of spreadable tofu products in fresh

\begin{tabular}{|c|c|c|c|c|c|c||}
\hline \multirow{2}{*}{ Parameters } & \multicolumn{7}{|c||}{ Values in spreadable tofu blends } \\
\cline { 2 - 7 } & C & T1 & T2 & T3 & T4 & T5 \\
\hline \hline L & 80.16 & 79.37 & 76.12 & 79.28 & 75.70 & 75.40 \\
\hline A & -6.4 & -7.49 & -6.7 & -6.98 & -6.57 & -5.7 \\
\hline B & 17.44 & 18.24 & 18.08 & 18.29 & 20.13 & 18.95 \\
\hline H $^{*}$ & 69.8 & 82.2 & 69.67 & 69.11 & 71.91 & 73.26 \\
\hline C $^{*}$ & 18.58 & 19.72 & 18.94 & 19.57 & 21.17 & 20.11 \\
\hline Intensity & 82.29 & 81.79 & 78.53 & 81.65 & 78.60 & 77.96 \\
\hline \hline
\end{tabular}

C: spreadable tofu without any flavor, T1: spreadable tofu with Chopped green olives, T2: spreadable tofu with Mix ground black pepper 
and chopped green peppers, T3: spreadable tofu with sugar; T4: spreadable tofu with guava pulp, T5: spreadable tofu with peach pulp, $\mathrm{C}^{*}$ : Chroma, $\mathrm{H}^{*}$ : Hue (he), tone angle or color

Similar observation was noticed by Jayasena, et al. (2010) reported that A white, creamy white or light yellow color would be considered as a desirable tofu characteristic that ascribed to ingredients kinds in control and treatments.

\section{- Texture profile analysis}

Table (2) illustrated texture properties of spreadable tofu blend. Data indicated as hardness ranged $(1.2-8.4 \mathrm{~N})$, cohesiveness $(0.19-0.63)$, springiness $(2.48-8.00 \mathrm{~mm})$, gumminess $(0.6-2.6 \mathrm{~N})$ and chewiness (3.6912.66 m.j). The highest hardness values was treatment $\mathrm{T} 4$ which contain tofu with $20 \%$ guava pulp compared to control and other treatments.

Table 2. Textural profile analysis (TPA) of spreadable tofu products.

\begin{tabular}{|c|c|c|c|c|c|c||}
\hline \multirow{2}{*}{ Parameters } & Storage period & \multicolumn{6}{|c||}{ Ratio of tofu\% } \\
\cline { 2 - 7 } & (month) & $\mathrm{C}$ & $\mathrm{T} 1$ & $\mathrm{~T} 2$ & $\mathrm{~T} 3$ & $\mathrm{~T} 4$ \\
\hline \hline \multirow{3}{*}{ Hardness (N) } & Fresh & 2.7 & 2.1 & 3.9 & 6.4 & 6.8 \\
\cline { 2 - 7 } & 1 & 2.6 & 2 & 3.1 & 4 & 4.2 \\
\cline { 2 - 7 } & 2 & 2.5 & 1.9 & 2.9 & 3.8 & 3.7 \\
\cline { 2 - 7 } & 3 & 2.5 & 1.9 & 2.9 & 2.7 & 2.4 \\
\hline \multirow{4}{*}{ Cohesiveness(Ratio) } & Fresh & 0.63 & 0.59 & 0.38 & 0.45 & 0.6 \\
\cline { 2 - 7 } & 1 & 0.57 & 0.42 & 0.33 & 0.45 & 0.26 \\
\cline { 2 - 7 } & 2 & 0.55 & 0.4 & 0.28 & 0.44 & 0.26 \\
\cline { 2 - 7 } & 3 & 0.54 & 0.38 & 0.19 & 0.43 & 0.26 \\
\hline \multirow{3}{*}{$\begin{array}{c}\text { Springiness } \\
\text { (mm) }\end{array}$} & Fresh & 2.48 & 3.5 & 5.95 & 4.39 & 5.38 \\
\cline { 2 - 7 } & 1 & 4.53 & 6.04 & 6.02 & 5.69 & 5.43 \\
\cline { 2 - 7 } & 2 & 5.97 & 7.98 & 7.97 & 5.7 & 6.33 \\
\cline { 2 - 7 } & 3 & 7.97 & 8 & 8 & 7.96 & 7.93 \\
\hline \multirow{3}{*}{ Cumminess (N) } & Fresh & 1.7 & 1.1 & 1.3 & 1.9 & 1.8 \\
\cline { 2 - 7 } & 1 & 1.48 & 0.9 & 1 & 1.7 & 1.5 \\
\cline { 2 - 7 } & 2 & 1.4 & 0.8 & 0.8 & 1.5 & 1.4 \\
\cline { 2 - 7 } & 3 & 1.38 & 0.7 & 0.6 & 1.2 & 1.1 \\
\hline \multirow{3}{*}{ Chewiness (m.j) } & Fresh & 11 & 6.95 & 10.13 & 12.66 & 11.35 \\
\cline { 2 - 7 } & 1 & 10.89 & 6.85 & 8.90 & 9.68 & 9.64 \\
\cline { 2 - 7 } & 2 & 6.54 & 6.19 & 7.24 & 6.58 & 6.44 \\
\cline { 2 - 7 } & 3 & 4.17 & 6.19 & 3.69 & 4.62 & 4.52 \\
\hline \hline
\end{tabular}


C: spreadable tofu without any flavor, T1: spreadable tofu with Chopped green olives, T2: spreadable tofu with Mix ground black pepper and chopped green peppers, T3: spreadable tofu with sugar; T4: spreadable tofu with guava pulp, T5: spreadable tofu with peach pulp.

Cohesiveness, gumminess and chewiness was positively related to the hardness of treatments compared to springiness took the opposite line with the hardness. These findings agree with those of Gholamhosseinpour et al. (2018).

\section{- Meltability}

Obtained data in Table (3) showed that meltability value in control, T1, T2, T3, T4 and T5 ranged (49-72), (33-55), (42-53), (35-71), (32-70) and (31-70), respectively. Nevertheless, the control showed the highest value compared to other treatments.

Table 3. Change in meltability ( $\mathrm{mm}$ ) of spreadable tofu products.

\begin{tabular}{|c|c|c|c|c|c|c||}
\hline \hline \multirow{2}{*}{$\begin{array}{c}\text { Storage } \\
\text { period } \\
\text { (month) }\end{array}$} & \multicolumn{6}{|c||}{ Spreadable tofu blends } \\
\cline { 2 - 7 } & $\mathrm{C}$ & $\mathrm{T} 1$ & $\mathrm{~T} 2$ & $\mathrm{~T} 3$ & $\mathrm{~T} 4$ & $\mathrm{~T} 5$ \\
\hline \hline Fresh & 72 & 55 & 53 & 71 & 70 & 70 \\
\hline 1 & 68.8 & 44.1 & 52 & 66 & 54 & 50.5 \\
\hline 2 & 56.1 & 46 & 47 & 53.5 & 51 & 47 \\
\hline 3 & 49 & 33 & 41 & 35 & 32 & 31 \\
\hline
\end{tabular}

C: spreadable tofu without any flavor, T1: spreadable tofu with Chopped green olives, T2: spreadable tofu with Mix ground black pepper and chopped green peppers, T3: spreadable tofu with sugar; T4: spreadable tofu with guava pulp, T5: spreadable tofu with peach pulp.

These results in harmony with Farahmandfar et al (2010, 2011) pproved that the decrease in stretch ability could be due to less percentage of casein available for conversion to mono-calcium-paracaseinate by the addition of soy solids, also the spreads became less rubbery, lack elasticity, impaired flow and stretchability with increasing substitution of plant protein e. g., soy protein. 


\section{REFRANCES}

- Abbaspour, N.; Hurrell, R. and Kelishadi, R. (2014). Review on iron and its importance for human health. J. Res. Med. Sci. ,19(2):164-74.

- Agrahar, M. (2014). Effect of sprouting of soybean on the chemical composition and quality of soymilk and tofu. J Food Sci Technol. 2014 May; 51(5): 915-921.

- Awad, R. A. ; Salama, W. M. and Farahat, A. M. (2014). Effect Of Lupine As Cheese Base Subtitution On Technological And Nutritional Properties Of Processed Cheese Analogue. Acta Sci. Pol., Technol. Aliment., 13(1): 55-64.

- Benassi,V. T.; Yamashita, F. ; Prudencio, S. H. (2011). A statistical approach to define some tofu processing conditions, Ciênc. Tecnol. Aliment., Campinas, 31(4): 897-904.

- Bolla, K.N. (2015). Soybean consumption and health benefits. International Journal of Scientific \& Technology Research , 4(07): 50- 53 .

- Bourne, M. (1978). Texture profile analysis. Food Tech., 32, 62.

- Brewer, M. S. (2011) . Natural antioxidants: sources, compounds, mechanisms of action, and potential applications. Comprehensive Reviews in Food Science and Food Safety, 10(4): 221-247.

- Chauhan AK, Singh S, Singh RP, Kumar A (2014). Determination of Antioxidant Capacity, Total Phenolics and Antimicrobial Properties of SprayDried Guava Extract for Value-Added Processing. J Food Process Technol, 5: 368-377.

- Emkey, R.D. and Emkey, G,R.(2012). Calcium metabolism and correcting calcium deficiencies. Endocrinol Metab. Clin. North Am., 41(3):527-56.

- Farahmandfar, R. ; Mazaheri T. M.; Razavi, S. M. A. and Habibi N. M. B. (2010). Effect of soy cheese and trisodium citrate on pizza cheese. International Journal of Food Engineering ,6(5): 1-9.

- Farahmandfar, R. ; Mazaheri T. M.; Razavi, S. M. A. and Habibi N. M. B. ( 2011). Effect of trisodium citrate concentration and soy cheese on meltability of pizza cheese. International Journal of Food Properties,14:697-707. 
- Some physiochemical and rheological properties of prepared spreadable tofu blends

- Francis, F.G. (2000). Anthocyanins and brteslains composition and applications . Cereal Foods World, 45:208-213.

- Gholamhosseinpour , .A. A. ; Mazaheri M. Tehrani; Razavi. S. M. A (2018). Optimization of textural characteristics of analogue UF-Feta cheese made from dairy and non-dairy ingredients. Iranian Food Science and Technology Research Journal , 13( 6): 80-91

- Henson, I.E. (2012). A brief history of the palm oil. In Palm Oil: Production, Processing, Characterization and Uses, AOCS Press: Urbana, IL, USA.

- Hui, Y.H. ; Evranuz, E.O. ; Erten, H. ; Bingöl, G. Flores, M.E.J. (2015). Fermentation, Pickling, and Turkish Table Olives. Handbook of Vegetable Preservation and Processing, 2nd ed, Chapter: 10, Publisher: CRC Press, pp.209230.

- Igbokwe, G.E.; Aniakor, G.C.; Anagonye, C.O. (2013). Determination of $\beta$ Carotene \& Vitamin C content of Fresh Green Pepper (Capsicum annnum), Fresh Red Pepper (Capsicum annum) and Fresh Tomatoes (Solanum lycopersicum) Fruits. Bioscientist, 1:89-93.

- Iordănescu, O.A. and Micu, R. (2012). General and special fruit tree culture, Ed. Mirton, Timiúoara, p. 45. check

- Jayasena, V; Khu, W.S.; and Nasar-Abbas, S.M. (2010). The Development and Sensory Acceptability Of Lupin-Based Tofu. Journal of food quality, 33(1): 85- 97.

- Kang, C.S.; Byun, G.H. and Kang, Y.C. (2014). Patent Application Publication (10) Pub. No.: US 2014/0302199 A1. (43) Pub, In Hwan Park, Seong Jun Int.; Seung Woo Nam.

- Lim, K.; Dolan, K.D. and Mitzi, M. (2011). Effects of spray drying on antioxidant capacity and anthocyanidin content of blueberry by-products. Journal of Food Science 7: H156-H164.

- Marinova,D.; Ribarova, F. and Atanassova M. (2005). Total Phenolics and total flavonoids in bulgarian fruits and vegetables. Journal of the University of Chemical Technology and Metallurgy, 40(3): 255-260. 
- Mchugh, T. (2016). How tofu is made. PA citation, retrieved 1 October 2017 from https://medicalxpress.com/news/l

- Metwally, A.M.;Omar, A.A.; Harraz, F.M. and El Sohafy. S.M. (2010) Phytochemical investigation and antimicrobial activity of Psidium guajava L. leaves. Pharmacogn Mag 6: 212-218

- Mueller, K. and Hingst, J.(2013) The athlete's guide to sports supplements. Illinois, Ill.: Human Kinetics.

- Pathare, B.P. and Opara, U.L. and Al-Said, F.A.J. (2012). Colour Measurement and analysis in fresh and processed foods: A review. Food Bioprocess Technology, 9: 1-28 .

- Rekha, C. R. and G. Vijayalakshmi, G. (2013). Influence of processing parameters on the quality of soycurd (tofu). J Food Sci Technol., 50(1): 176180.

- Rines, A.K. and Ardehali, H.( 2013). Transition metals and mitochondrial metabolism in the heart. J. Mol. Cell Cardiol., 55:50-7.

- Slavin, J.L. and Lloyd, B. (2012). Health Benefits of Fruits and Vegetables. Advances in Nutrition, 3(4): 506-516.

- Szczesniak, A.; Brandt, M. and Freidman, H. (1963). Development of standard rating scales for mechanical parameters and correlation between the objective and sensory texture measurements. Food Tech., 22: 50

- Wang, H. H. and Sun ,D.W.( 2002). Melting characteristics of cheese: Analysis on effects of cheese dimensions using image processing techniques . Journal of Food Engineering, 52: 279-284.

- Willett, W.; Sesso, H. and Rimm, E. (2013). Demystifying nutrition: the value of food, vitamins and supplements. Longwood Seminars, Harvard Health Publications, 77 Avenue Louis Pasteur, Boston, pp 1-45. 


\section{بهض الفصائص الفيزيوكيميائية والريولوجية لفلطات التوفه القابلة للفرد}

$$
\text { الملخص العربي }
$$

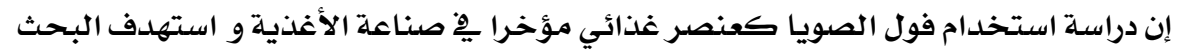

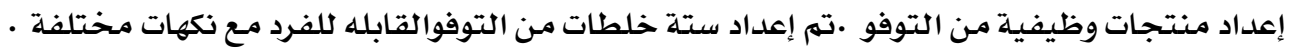

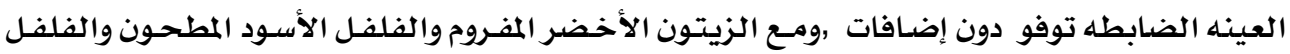

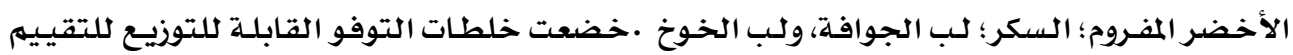

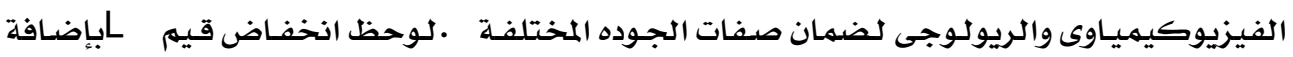

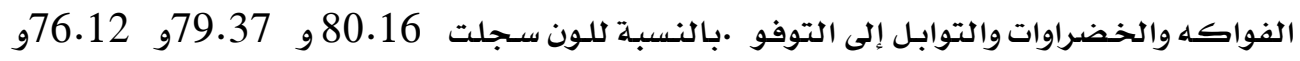

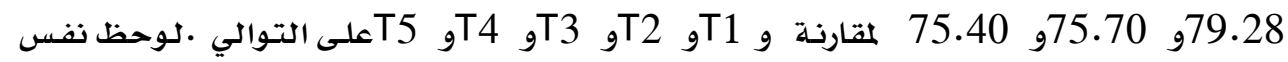

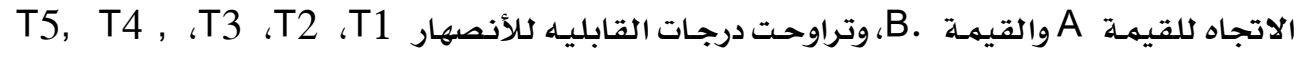

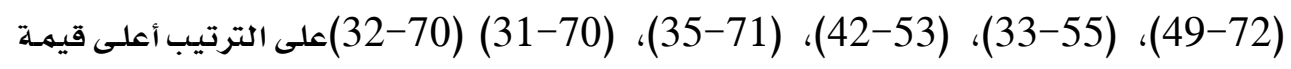

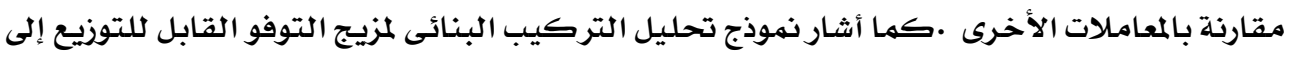

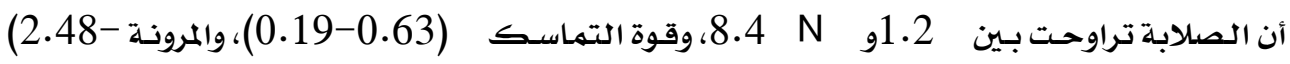

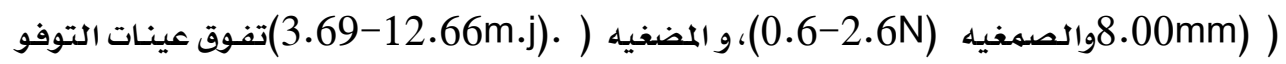
القابل للفرد ذات النكهات الطبيعية المختلفة مقارنة بالعينه الضابطه.

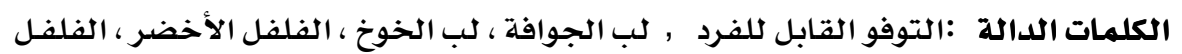

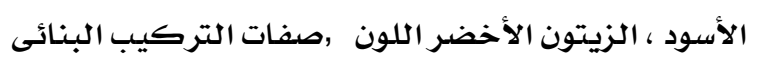

